\title{
Risk assessment and distribution research of radionuclide Cs-134 for typical fishing ground in the North Pacific Ocean
}

\author{
TANG Feng-hua ${ }^{1, a}$, ZHANG Sheng-mao ${ }^{\text {2,b }}$, Cui Xue-seng ${ }^{3, c}$ and ZHANG \\ Bian-bian $^{4, d}$ \\ ${ }^{1}$ Key Laboratory of East China Sea \& Oceanic Fishery Resources Exploitation and Utilization, \\ Ministry of Agriculture, East China Sea fisheries Research Institute, Chinese Academy of Fishery \\ Sciences, Shanghai 200090, P.R. China \\ ${ }^{2}$ Room 606, building 6, no. 300, military road, Yangpu district, Shanghai, China \\ ${ }^{3}$ Room 606, building 6, no. 300, military road, Yangpu district, Shanghai, China \\ ${ }^{4}$ Room 606, building 6, no. 300, military road, Yangpu district, Shanghai, China \\ a $\underline{\text { f-h-tang@163.com, }}{ }^{\mathrm{b}}$ zhangsm@163.com, ${ }^{\mathrm{c} C \text { Cuiss@163.com, }}{ }^{\mathrm{d}}$ zhangbb@163.com
}

Keywords: Fukushima accident; Radiation nuclide; North Pacific high seas; Neon flying squid; Evaluation

Abstract. Using typical fish samples collected in the north Pacific on 2011 to 2012, adopting High Purity Germanium (High Purity Germanium) passive scale efficiency detect gamma spectrometer, radioactive nuclide ${ }^{134} \mathrm{Cs}$ was detected in all samples. Using classification and sub-organs and other treatment methods to compare and analyses, we found that in 2011 , the highest ${ }^{134} \mathrm{Cs}$ nuclide content is in the $155^{\circ} 5^{\prime} \mathrm{E}, 42^{\circ} 10^{\prime} \mathrm{N}$ stance, as high as $4.925 \mathrm{~Bq}^{\circ} \mathrm{kg}^{-1}$; the lowest in $39^{\circ} 51^{\prime} 132^{\circ} 44^{\prime} \mathrm{E}, \mathrm{N}$ the waters of the sea, nuclide specific activity value does not exceed the bottom level. In the North Pacific ocean, the ${ }^{134} \mathrm{Cs}^{\text {'s }} \mathrm{overall}$ radionuclide content from south to north was decreasing. In 2012, the highest ${ }^{134} \mathrm{Cs}$ nuclide content is in 58 'E, $43^{\circ} 155^{\circ} 34^{\prime} \mathrm{N}, 0.159 \mathrm{~Bq} \cdot \mathrm{kg}^{-1}$; the lowest in $131^{\circ} 47^{\prime} \mathrm{E}$ 、 $36^{\circ} 50^{\prime} \mathrm{N}$ in sea waters position, the nuclide content in the high seas ${ }^{134} \mathrm{Cs}$ showed a trend of increased distribution from west to east. From content distribution of two different tissues of the Neon flying squid, visceral is the highest enrichment of nuclide $134 \mathrm{Cs}$ and the head is lowest. According to the estimation results, the ${ }^{134} \mathrm{Cs}$ Radionuclide concentrations and radiation increment now in the north Pacific are within an environmental safety concentration limits.

\section{Introduction}

The fishery resources of North Pacific Ocean in $37^{\circ} \mathrm{N} \sim 46^{\circ} \mathrm{N} 、 140^{\circ} \mathrm{N} \sim 160^{\circ} \mathrm{W}$ is very abundant, especially the small-sized fishes of upper-middle fishery, which is an important place of origin of the world pelagic fishery. Currently, our country is carrying out commercial fishery productions in North Pacific Ocean, such as squid fishing, stick-held net, light-purse seine etc [1, 2]. The Ommastrephe bartramii is rich in this area, and distributed in the Pacific Ocean Kuroshio Current and Oyashio current intersection mixed zone and the mixed water eastward of the subarctic oceanic front mixed zone, which is one of the most main varieties of the high seas fishing in our country [3, 4, 5]. In March 2011, Tsunami in Japan on the Pacific Coast has caused Fukushima nuclear leakage and large amount of radioactive releases have ran into the environment. After radioactive nuclide have ran into the marine environment through the way as atmospheric deposition and water migration, the interconnected ocean water and fishery organisms will be polluted, and finally a certain degree of radiation effects will caused on the environment and the creatures. Marine creatures will not only absorb and accumulate radioactive substances, and could also take pollutant into nonpolluting sea areas by the way of migration and drift, which will become radioactive pollutant carriers and communicators. Therefore, contaminated waters impacts on marine creatures is hard to estimate[6,7,8]. Cesium-134, nuclide symbol as ${ }^{134} \mathrm{Cs}$, which is a kind of cesium isotopes, has strong radioactivity and 2 years half-time period. Cs-134 is mainly comes from nuclear power plants liquid and gaseous effluent, treatment plant waste gas and discharging of wastewater, nuclear accident 
release near the ground, radioactive nuclear fission products, and high energy electron accelerator induced radionuclides, which will have effects on organisms when reach to a certain dosage[9,10].

By detecting the nuclear radiation content in marine organisms and further to estimate the radiation dosage content that human have received through the food chain transmission, so as to learn marine creatures concentration ability and regularity of different radiation is of great significance to estimate the biological radiation dosage rate and protect the health of ecological system[11].Domestic research on Fukushima accident radiation research and testing works is mainly focused on the safety of offshore aquatic products of china. At present our country to Japan Fukushima nuclear leakage radioactive influence on North Pacific high seas marine creatures is less reported, although some has reported [12], they are mainly aiming at the radionuclide content in the water. This research is mainly aiming at the ${ }^{134} \mathrm{Cs}$ enrichment and distribution levels on major fishery organisms in the North Pacific high seas, so as to make up this vacancy and to supplement the subsequent impacts of Fukushima nuclear leakage accident and in order to know the effects of radiation on main fishing grounds of North Pacific high seas, finally to provide technical supervision and guarantee on pelagic fishery production for our country.

\section{Material and Method}

\section{Sampling Method}

The sampling areas are mainly distributed in the North Pacific high seas of the traditional Squid fishing grounds. The main sampling range is $150 \sim 160^{\circ} \mathrm{E} 、 39 \sim 45^{\circ} \mathrm{N}$, in addition there are sites in Central-South Japan sea, the main sampling objects are soft fishes and other marine creatures, at the same time we have measured the biological relevant body length, weight of the samples ; And frozen it come back to laboratory for further processing and testing. The figure 1 is sampling area, including sampling sites in 2011 and 2012 respectively and the main research object - squid fish.
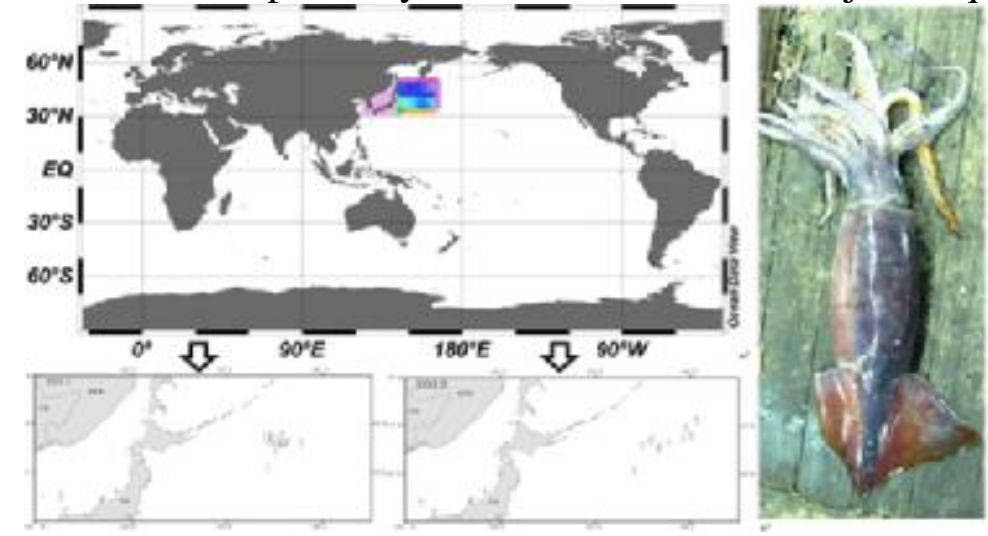

Fig.1 Distribution position of investigation and main research object

\section{Pretreatment Method and Detection}

(1) ${ }^{134}$ Cs activity determination in biological samples

The nuclide testing instruments are High Purity Germanium (High Purity Germanium, HPGe) passive scale efficiency detect gamma spectrometer made by American CANBERRA Company. IAEA-414 standard [14] taken as the standard reference for radioactive nuclide's measurement accuracy.Samples are putted into the $\gamma$ spectrometer measuring bottle after weighed and made into the same shape of standard source, the activity concentration calculation formula is[15]:

$$
A=a \mathrm{~s} \cdot W \cdot r /[\varepsilon(E) \cdot P \cdot m]
$$

(2)The risk evaluation method

Taking entropy value method [16] as an evaluation of the risk of Fukushima nuclear accident for marine organisms, that is to use obtained radioactive nuclide content of detected marine organisms to evaluate or to compare the entropy value of radiation dosage rate with standard rate, and if the result is more than 1, there is the risk, if less than 1, none. ERICA is a set of software program with build-in database which is developed form Java, and users can make layered evaluation of environmental risk 
with this tool.

\section{Results and Analysis}

\section{The Geographical Distribution of ${ }^{134}$ Cs Nuclide in Fishing Grounds}

The distribution of ${ }^{134} \mathrm{Cs}$ nuclide in detected sites is shown in picture 2. In 2011, the highest ${ }^{134} \mathrm{Cs}$ nuclide content is in sites of $155^{\circ} 5^{\prime} \mathrm{E} 、 42^{\circ} 10^{\prime} \mathrm{N}$, reaching to $4.93 \mathrm{~Bq} \cdot \mathrm{kg}^{-1}$; and the lowest is in $132^{\circ} 44^{\prime} \mathrm{E}$, $39^{\circ} 51^{\prime} \mathrm{N}$ of Japan sea, where the nuclide specific activity is in the bottom level. In 2012, the highest ${ }^{134} \mathrm{Cs}$ nuclide content is in sites of $155^{\circ} 58^{\prime} \mathrm{E}, 43^{\circ} 34^{\prime} \mathrm{N}$, reaching to $0.89 \mathrm{~Bq} \cdot \mathrm{kg}^{-1}$; and the lowest is still in $131^{\circ} 47^{\prime} \mathrm{E}, 36^{\circ} 50^{\prime} \mathrm{N}$ of Japan sea, the content of ${ }^{134} \mathrm{Cs}$ nuclide appears an increased distribution trend from east to west in North Pacific high seas.

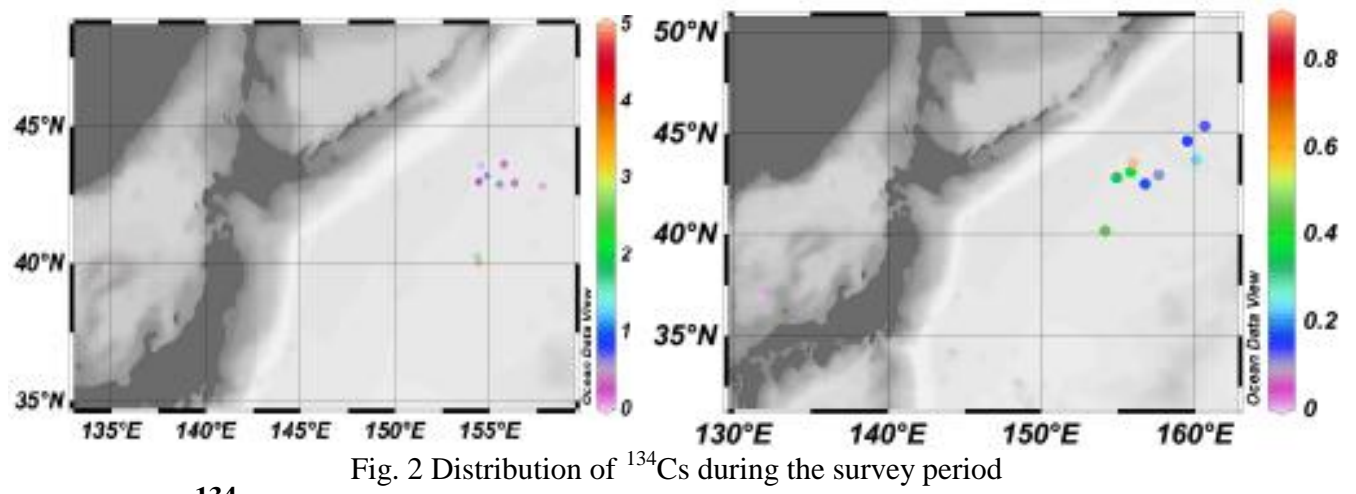

\section{The Distribution of ${ }^{134} \mathrm{Cs}$ Nuclide in Marine Organisms}

Equalizing ${ }^{134} \mathrm{Cs}$ content in all detected and the same kind of marine organisms and let that value as the distribution value of it. The highest value is in sharks, , reaching to $0.92 \mathrm{~Bq} \cdot \mathrm{kg}^{-1}$; then followed Coryphaena hippurus, Cololabis saira Brevoort、Ommastrephe bartramii、 and Moerella iridescens , the lowest is in Todarodes pacificus on Japan sea, which is as same as the bottom level. But basically the nuclide content of ${ }^{134} \mathrm{Cs}$ in almost every marine organism has reduced, among them the highest was in Coryphaena hippurus, reaching to $0.41 \mathrm{~Bq} \cdot \mathrm{kg}^{-1}$, and the next is Cololabis saira Brevoort. Ommastrephe bartramii and sharks, the lowest was still in Todarodes pacificus in Japan sea.

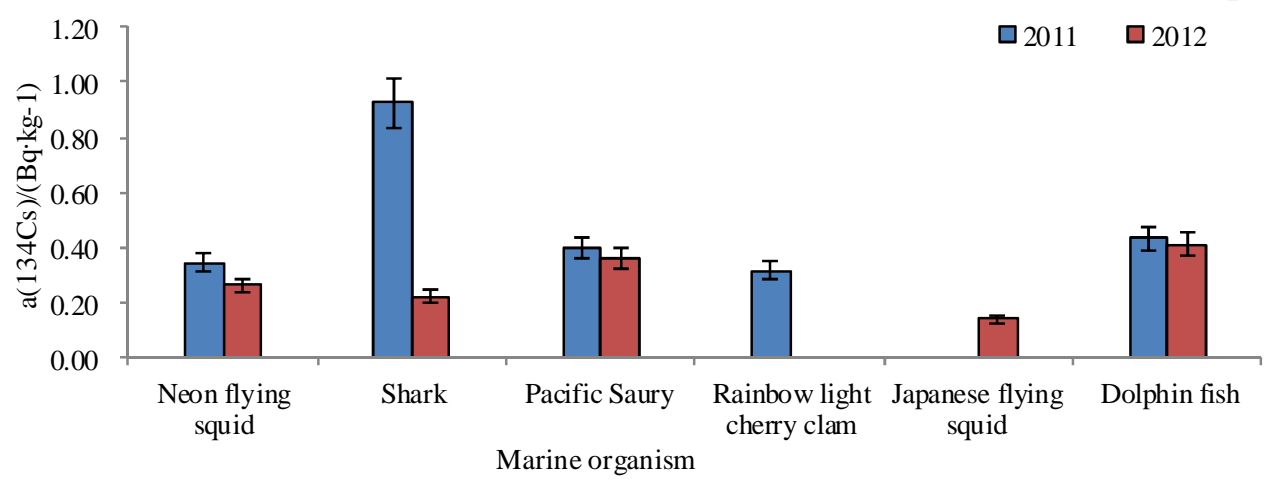

\section{Distribution and Variation Of ${ }^{\mathbf{1 3 4}} \mathrm{Cs}$ Nuclide in Neon flying Squid}

In 2011, among the different kind of soft fishes, the highest ${ }^{134} \mathrm{Cs}$ nuclide content was in 250 300mm group, reaching to $0.67 \mathrm{~Bq} \cdot \mathrm{kg}^{-1}$; and the lowest was in 150 200mm group , only 0.17 $\mathrm{Bq} \cdot \mathrm{kg}^{-1}$. In 2012, the highest ${ }^{134} \mathrm{Cs}$ nuclide content was in $300 \sim 350 \mathrm{~mm}$ group, reaching to 0.71 $\mathrm{Bq} \cdot \mathrm{kg}^{-1}$; And the lowest was in $>400 \mathrm{~mm}$ group, only $0.13 \mathrm{~Bq} \cdot \mathrm{kg}^{-1}$. As shown in figure 4 below, there is no obvious linear increase or decline with the rising body length of ${ }^{134} \mathrm{Cs}$ nuclide's distribution. 


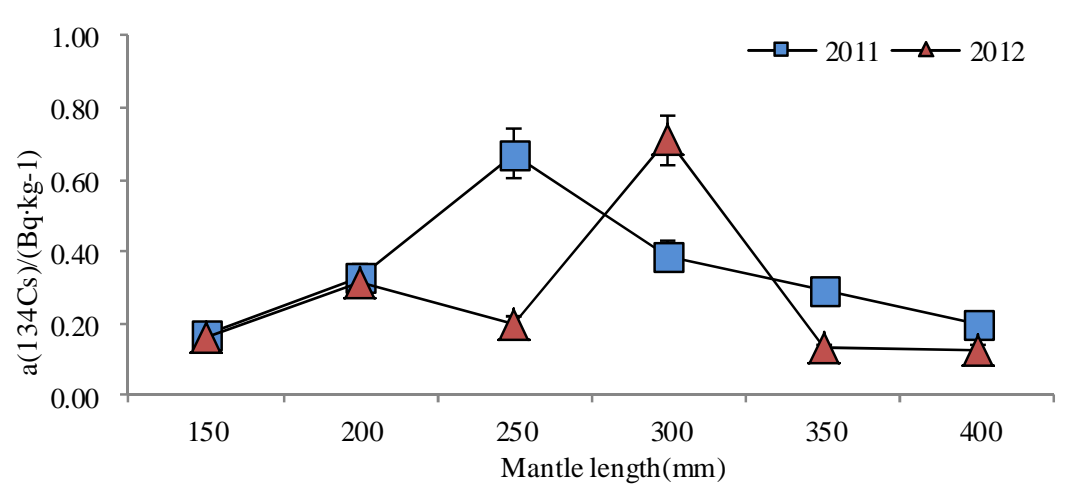

Fig. $4{ }^{134} \mathrm{Cs}$ nuclide content distribution of different individual characteristics

${ }^{134} \mathrm{Cs}$ nuclide content in specific parts of soft fishes is shown in picture 6.In 2011 , the highest was in kidney, reaching to $0.70 \mathrm{~Bq} \cdot \mathrm{kg}^{-1}$, the next was fin, trunk, head. In 2012 , the highest was also in kidney, reaching to $0.80 \mathrm{~Bq} \cdot \mathrm{kg}^{-1}$, the next was trunk, head, fin. From the content distribution of different organic parts of soft fishes in two years, the highest ${ }^{134} \mathrm{Cs}$ content tissues of viscera is kidney, and the head have more lower nuclide content.

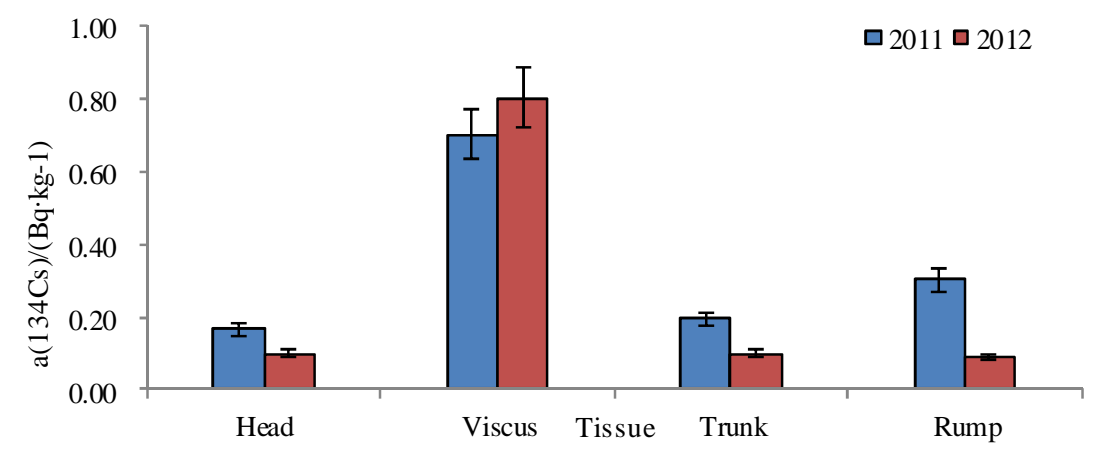

Fig. $5{ }^{134} \mathrm{Cs}$ nuclide content distribution of in different tissues of squid

\section{Risk Assessment of Nuclide in Fishing Ground}

Setting $100 \mathrm{Bg} \cdot \mathrm{kg}^{-1}$ as reference value which is based on the radioactive nuclide content in marine organism in the table ,the radioactive nuclide content of ${ }^{134} \mathrm{Cs}$ in every detected marine organism of each sites in North Pacific high seas fishing ground is less than $1(100 \%)$ compared with the entropy of reference value, especially the entropy value has dropped close to parts per million in 2012 ,it means that the detected ${ }^{134} \mathrm{Cs}$ content in mainly fishery organism of North Pacific high seas was not exceeded reference value in the consecutive two years, and have been decreasing year by year ,also much less than reference value, so it means that this nuclide basically does not have risk in this sea area at present. 
Tab. 1 Results of total radiation dose rate for ERICA tools ${ }^{134} \mathrm{Cs} 2$ level evaluations

\begin{tabular}{cccc}
\hline Biota & External Dose Rate $\left(\mathbf{m G y} \cdot \mathbf{h}^{-\mathbf{1}}\right)$ & $\begin{array}{c}\text { Internal Dose Rate } \\
\left(\mathbf{m G y} \cdot \mathbf{h}^{\mathbf{- 1}}\right)\end{array}$ & Total Dose Rate $\left(\mathbf{m G y} \cdot \mathbf{h}^{\mathbf{1}}\right)$ \\
\hline Pelagic fish & $6.24 \mathrm{E}-06$ & $1.63 \mathrm{E}-05$ & $1.19 \mathrm{E}-04$ \\
Benthic fish & $5.56 \mathrm{E}-06$ & $3.06 \mathrm{E}-04$ & $2.22 \mathrm{E}-04$ \\
Phytoplankton & $2.34 \mathrm{E}-06$ & $1.24 \mathrm{E}-06$ & $1.39 \mathrm{E}-04$ \\
Zooplankton & $1.11 \mathrm{E}-05$ & $6.30 \mathrm{E}-06$ & $2.16 \mathrm{E}-04$ \\
Crustaceans & $9.66 \mathrm{E}-06$ & $9.34 \mathrm{E}-06$ & $3.06 \mathrm{E}-04$ \\
Benthic mollusks & $1.88 \mathrm{E}-06$ & $1.13 \mathrm{E}-05$ & $1.96 \mathrm{E}-04$ \\
Polychaete worms & $3.21 \mathrm{E}-06$ & $2.33 \mathrm{E}-06$ & $1.12 \mathrm{E}-03$ \\
Reptiles & $1.32 \mathrm{E}-05$ & $3.11 \mathrm{E}-05$ & $3.24 \mathrm{E}-04$ \\
Sea anemones or true & $3.23 \mathrm{E}-05$ & $1.22 \mathrm{E}-05$ & $3.59 \mathrm{E}-04$ \\
corals -colony & $9.78 \mathrm{E}-05$ & & $1.27 \mathrm{E}-04$ \\
Sea anemones or true & $1.23 \mathrm{E}-05$ & $1.62 \mathrm{E}-05$ & $3.34 \mathrm{E}-04$ \\
corals-polyp & $6.55 \mathrm{E}-04$ & $3.86 \mathrm{E}-05$ & $3.33 \mathrm{E}-04$ \\
Mammals & & $1.36 \mathrm{E}-05$ & \\
Macroalgae & & & \\
\hline
\end{tabular}

\section{Acknowledgements}

This work was financially supported by the national science and technology support program (2013BAD13B01) and the Open Research Fund of State Key Laboratory of Estuarine and Coastal Research (SKLEC201206).

\section{References}

[1] Fan W, Wu Y M, Cui X S. The study on fishing ground of neon flying squid, Ommastrephes bartramii, and ocean environment based on remote sensing data in the Northwest Pacific Ocean. J. Oceanol. \& Limnol. China, 27(2):408-414 (2009).

[2] Chen X J, Liu B L. The Catch Distribution of Ommastrephes batramii in Squid Jigging Fishery and the Relationship between Fishing Ground and SST in the North Pacific Ocean in 2004. Mari.Sci. Bull., 8(2):83-90(2006).

[3] Chen C S. Abundance trends of two neon flying squid (Ommastrephes bartramii) stocks in the North Pacific. ICES Journal of Marine Science, 67: 1-10( 2010).

[4] Yatsu A, Watanabe T. Interannual variability in neon flying squid abundance and oceanographic conditions in the Central North Pacific Ocean(1982-1992 ). Tokyo: Bul1 Natl Res Inst Farseas Fish. 33:123-138(1996).

[5] Fan Wei, Wu Yumei, Cui Xuesen. The study on fishing ground of neon flying squid, Ommastrephes bartramii, and ocean environment based on remote sensing data in the Northwest Pacific Ocean. Chinese Journal of Oceanology and Limnology, 27(2):408-414(2009).

[6] Hyoe T, Masashi K, Shinji O. Radiocesiums $\left({ }^{134} \mathrm{Cs},{ }^{137} \mathrm{Cs}\right)$ in zooplankton in the watersof Miyagi, Fukushima and Ibaraki Prefectures. J Radioanal Nucl Chem, 303:1265-1271(2015).

[7] Buesseler KO, Jayne SR, Fisher NS, et al. Fukushima-derived radionuclides in the ocean and biota off Japan. Proceedings of the National Academy of Sciences, 109:5984-5988(2012).

[8] Shi J-J. Nuclear accident empact on the ecological environment. Journal of Nuclear Agricultural Sciences, 25(2): 397- 403 (2011).

[9] Inoue M, Yoneoka S, Ochiai S, et al. Lateral and temporal variations in Fukushima Dai-ichi NPP-derived 134Cs and 137Cs in marine sediments in/around the Sado Basin. Sea of Japan. J Radioanal Nucl Chem, 303:1313-1316(2015).

[10] National standard of the People's Republic of China. GB/T 16145 Water radionuclide gamma energy spectrum analysis method (1995). 
[11] Kameník J, Dulaiova H, Buesseler K O, et al. Cesium-134 and 137 activities in the central North Pacific Ocean after the Fukushima Dai-ichi nuclear power plant accident. Biogeosciences, 10:6045-6052 (2013).

[12] Wu M, He J-H, Wang F-F, et al. Radioactive status of seawater in the northwest Pacific more than one year after the Fukushima nuclear accident. Scientific Reports, 5:7757-7757(2015).

[13] Tang F-H, Wang J-L, Liu D-T, et al. Distribution of Fukushima Accident-derived Radionuclides in Neon Flying Squid in the North Pacific Ocean. Journal of Agro-Environment Science, 32(10): 2066-2071 (2013)

[14] Wu M He JH, Wang FF, et al. Radioactive status of seawater in the northwest Pacific more than one year after the Fukushima nuclear accident. Scientific Reports, 5:7757-7757(2015)

[15] Morino Y, Ohara T, Nishizawa M. Atmospheric behavior, deposition, and budget of radioactive materials from the Fukushima Daiichi nuclear power plant in March 2011. Geophys Res Lett, 38: L00G11(2011).

[16] Xu H-N, Yu T. Ecological risk assessment of marine organisms and radioactive monitoring progress after Japan's Fukushima. China environmental science society academic essays, 1824-1835 (2015) 